\title{
THE ROLE OF FOOD SCIENCE AND TECHNOLOGY FOR INDONESIAN INDIGENOUS FOOD PRODUCT DEVELOPMENT TO ACHIEVE FOOD SECURITY
}

\author{
Winiati P Rahayu ${ }^{1,2 *}$, Irma Septiani ${ }^{1)}$
}

\author{
${ }^{1}$ Department of Food Science and Technology, IPB University (Bogor Agricultural University), Bogor, Indonesia \\ ${ }^{2}$ Southeast Asian Food and Agricultural Science and Technology (SEAFAST) Center, IPB University (Bogor Agricultural University), \\ Bogor, Indonesia \\ *Corresponding author: wpr@apps.ipb.ac.id
}

\begin{abstract}
Food insecurity is remaining an unsolved problem since the continuous increase in human populations demands an increased supply of food. The objective of this paper was to present Indonesian indigenous food product development as an answer to the food security problem. It could be conducted by presenting the potentials of indigenous foods, creating advances in food technology, and arranging strategies that needed to develop indigenous food products, particularly as a food technologist. The suggested strategies were: choosing the raw material that is abundantly available in the local area, assessing its superiorities, doing a feasibility study, enhancing the food product's safety and quality by applying good manufacturing practices and using environmentally friendly packaging, and promoting the products through modern channels such as the supermarket. This would allow nutritious and safe indigenous food products to become competitive and widely impacting food products that can bring food security into a reality.
\end{abstract}

Keywords: food science and technology, food security, indigenous food

\section{INTRODUCTION}

Food security exists when all people, at all times, have physical and economic access to sufficient, safe, and nutritious food that meets their dietary needs and food preferences for active and healthy life (World Food Summit, 1996). Food and Agriculture Organization (FAO) of The United Nations reported that in 2014-2016, it is estimated that 795 million people in the world or about one out of nine people are undernourished, which means that they get inadequate dietary energy intake (WFP, 2015). This data shows that the world is still facing the problem of food security. The state of food security is also influenced by the number of living people. In July 2015, the world population reached 7.3 billion, and it is projected to have the addition of 83 million people in 2016. Continued population growth until 2050 is almost inevitable, even if the decline of fertility accelerates. There is an 80 percent probability that the population of the world will be between 8.4 and 8.6 billion in 2030 , between 9.4 and 10 billion in 2050 and between 10 and 12.5 billion in 2100 (UN, 2015). These conditions give an alarm of food security threat in the future that requires our attention.

Food security has 4 dimensions, which are physical availability of food, economic and physical access to food, food utilization, and stability of the other three dimensions over time (FAO, 2008). Agriculture intensification and productivity and agricultural yield improvement could be done to achieve the physical availability of food, yet there are many other uncertainties such as the impacts of climate change. Therefore, other measures for achieving the first dimension of food security should be explored. The availability of food in each region will be different from the type and amount. Therefore, the availability of food in each region must be utilized optimally. It is important for people from different areas to creatively make food as a fundamental need of human beings.

The works of people through civilization have created cultures. It is common knowledge that Indonesia is so rich in terms of cultures. One of the best parts of the cultures is the food product, both in the form of processed food and cuisines. With the help of the development of technology, hundreds of foods were born in Indonesia. These foods are unique because each has its appealing points that stand out from the others (Rahayu and Lian, 2020). These regionspecified food products are known as indigenous food. Indigenous means food naturally existing or originating in a place or country rather than arriving from another place (Tontisirin, 2014). That kind of food is adapted to the local environment and still contain historical patterns of usage systems (Lutaladio, Burlingame, and Crews, 2010). Indigenous foods, neglected and derided by many in the agriculture and food industries as well as by urban consumers, could be an important component in alleviating hunger (FAO, 2014). This paper aimed to present indigenous food product development as an answer to the food security problem.

\section{POTENTIAL INDIGENOUS FOODS}

Indigenous foods could be an answer to food security because they exist in every part of the world, thus giving the bigger opportunity to make food available for a vast number of people living in remote areas with minimally developed infrastructure. Rural people make up a high percentage of the hungry and malnourished in developing countries, and efforts to promote growth in agriculture and the rural sector could be an important component of a strategy for promoting inclusive growth and improving food security and nutrition. Improving the productivity of resources held by family farmers and smallholders is, in 
most cases, an essential element of inclusive growth and has broad implications for the livelihoods of the rural poor and the rural economy in general (FAO, IFAD and WFP, 2015). The development of indigenous foods in a way that improving the foods' availability and value will result on the achievement of food security in turn.

Cassava (Manihot esculenta) is produced in Indonesia around 23 to 24 million tonnes in a year (BKP, 2015). One of the products made from cassava is tiwul, which is used as a staple food in several regions in Java. Despite the existing opinion of tiwul as poor rural people's food, a major company in Indonesia has been investing in the development of tiwul. As the result, a more innovative fortified instant tiwul is available now, named "Titan", which is an abbreviation from "tiwul instan" (instant tiwul) (Gardjito et al., 2013). It has added values from providing convenience in its preparation and enhanced nutritional content. Another example is purple sweet potato (Ipomoea batatas L.), which is rich in nutritional value, except for protein and niacin. Besides simple starches, sweet potatoes are rich in complex carbohydrates, dietary fiber, iron, and vitamin content such as beta-carotene (a pro-vitamin A carotenoid), vitamin B2, vitamin C, and vitamin E. Additionally, it is packed with anthocyanins, which contains antioxidant and anti-inflammatory properties (Mohanraj and Sivasankar, 2014). In Indonesia, purple sweet potatoes have been used to make ice cream and noodles. Beside rich in carbohydrate sources, Indonesia also has indigenous sources of protein, one of them is fish. The production of fish in Indonesia is increasing continuously from 2010 to 2014, reaching 20 million tons in 2014 (BKP, 2015), which exhibits the opportunity of fish utilization to support food security. Some innovations of fish-based products are fish floss and fish chips. The three examples clearly show that indigenous foods have a big potential, from the productivity to the nutritional value, to be sources of energy and micronutrients needed by people.

However, many indigenous foods are still in inferiority, such as sago, one of indigenous food from Indonesia which is extracted from sago tree (Metroxylon sago). There are around 1.2 million hectares of wild stands of sago trees in Indonesia, and around 60 to 85 percent are found in Papua, which located in the most vulnerable sub-district in Indonesia (Rana, 2014; Rastika, 2015). Sago trees in the wild can produce dry carbohydrates around 25 tonnes/ hectare/year, yet it is still underutilized (Rana, 2014). The underutilized indigenous foods must be developed to increase their utilization; therefore, many people could get their benefits. The development of underutilized indigenous foods could be done by supporting the latest consumer demand trends. Sloan (2015) has listed top ten food trends, include the shift to fresh and refrigerated foods; alternating food consumption pattern in accordance to changes in lifestyles, eating patterns, and demographics; growth in snack consumption; search for new taste and kind of foods; use alternative foods; high breakfast food consumption; increasing local, organic, natural food consumption; the demand of whole foods; instant foods preference; and the tenth is health consumption pattern orientation. Indigenous food products, therefore, have the chance to fulfill the consumer's demand for new kinds of foods local, organic, and natural foods.

\section{FOOD TECHNOLOGY AS A TOOL FOR INDIGENOUS FOOD PRODUCT DEVELOPMENT}

Food technology, which simply means 'the application of food science', is the main tool for developing indigenous food products. Advances in food technology will support indigenous food product development. The fermentation technology has played its part behind the big name of Indonesian indigenous food. Since the age of the ancestor, fermentation has become an important piece of inheritance that serves to increase the quality of food products. The sensory value, digestibility, functional and other properties increase significantly because of it (Bourdichon et al., 2012). With the development of science and technology, new technologies have also emerged. Some of the latest advances from this field are:

1. Anjan Contractor has created a laptop-sized 3-D food printer that can create and cook a pizza by using powdered dough, tomato sauce, and cheese, for providing a meal for NASA long-distance space travel. The contractor also considered the future use of his food printer in refugee camps, where the people are very vulnerable to be food insecure because the technology used powdered ingredients that can be stored for a long time (Wolinsky, 2014).

2. Morphology and physicochemical properties of three Lilium (Liliaceae) bulb starches have been investigated and reported in the latest issue of the Journal of Food Science. It provided novel information about the morphology and physicochemical properties of bulb starches from three Lilium, comprised of one Lilium cultivar and two wild types commonly distributed in Western China, and provided with a systematical comparison of the results. It will support the utilization of Lilium starch resources (Yu et al., 2015).

3. Cold plasma can be used to control biofilms in the food industry. In order to effectively remove biofilms from the surfaces of food and food-contacted materials, cold plasma, as a novel non-thermal processing technology, is adopted in the food industry. The reactive species, etching effect, and control of quorum sensing are involved in the mechanisms responsible for anti-biofilms activity of cold plasma, which can be affected by a series of factors including gas composition, attachment surface, processing parameters, type of bacteria, biofilms thickness, etc. In the process of eliminating biofilms, cold plasma can exert minimum impact on the organoleptic properties of food products, while lipid oxidation is detected which needs special attention (Zhu et al, 2020).

4. Studies of starch-based aerogels have attracted widespread attention over the last decade, motivated by their environmental friendliness, biodegradability 
and unique properties. There are two main fabrication routes of starch-based aerogels based on their shapes: one is for monolith aerogel; another is for microsphere. The applications of starch-based aerogels have been extensively explored in food ingredients delivery, food packaging, and thermal isolation (Zheng et al, 2020).

5. Animal-free and plastic-free are two current trends in food technology. In vitro meat production is a novel idea of producing meat without involving animals with the help of tissue engineering techniques. This bio fabrication of complex living products by using various bioengineering techniques is a potential solution to reduce the ill effects of current meat production systems and can dramatically transform traditional animal-based agriculture by inventing "animal-free" meat and meat products (Bhat, Kumar, and Bhat, 2017). The use of plastic as packaging has been largely abandoned and currently, there is a lot of research on edible packaging. For example, edible packaging films can be produced from semi-refined kappa-carrageenan (SRC). The inexpensive $\mathrm{SRC}$ is a promising packaging material and has good potential to be used as an alternative polysaccharide material to produce edible biodegradable packaging films with improved mechanical and barrier properties (Farhan and Hani, 2017).

Other development of food technology needed to support indigenous food product development such as processing technology, in a particular technology to preserve the nutritional contents and increase shelf-life of indigenous foods, packaging technology, nano-technology, information technology (regarding food labeling), functional food technology, bioinformatics, and the omics (genomics, proteomics, nutrigenomics, metabolomics). Food technology, with all its advances, if seriously and continuously aimed to provide world food needs, by utilizing indigenous food products, could help to feed the world, especially people in vulnerable areas to the food crisis.

\section{FOOD TECHNOLOGISTS' ROLE}

As a vehicle, food technology needs a driver, and that is the role of food technologists. Food technologists should use the knowledge and skills they have received to develop and apply food technology for adding values to indigenous food. It aimed to create nutritious food accessible to people all over the world. To develop indigenous food products, some strategies can be used, chronologically listed as choosing the raw material that is abundantly available in the area, assessing its superiorities, doing a feasibility study, enhancing the food product's safety and quality, and promoting it through modern channels.

The first step of indigenous food product development is to list some raw materials that have the potency to be developed, i.e. the materials that are available with adequate quantities over time in the specific geographical area. This does not mean that seasonal crops cannot be selected. The point is to ensure that the raw materials are available to be used continuously from time to time, which means all year round or in some particular months every year. The second step is assessing the materials' superiorities, which including quality, safety, consumer acceptance, and economical value. The next step is doing a feasibility study, to decide which material will be further developed.

After a specific material has been selected, the quality and safety of the chosen material need to be improved to be able to meet the consumer's demand. This step can be done by giving training to the producer to apply good manufacturing practices and developing suitable packaging that could protect the product's quality as well as giving an attractive appearance for the consumer. One example is by using environmentally friendly packaging, which meets consumer's demand for environmental conservation. Food technologists can also develop methods for detecting pathogenic bacteria and other food contaminants; do food safety risk assessments; and develop methods for reducing, eliminating, and handling food safety risks to enhance the product's safety. Other measures that could be done to enhance indigenous food product safety and quality are developing functional food processing technology that is applicable to the product and researching to add knowledge about the product.

The final step is promoting the indigenous food product to increase its acceptance and utilization. There are many available ways to do this, especially with the advances in information technology. One success story comes from Indonesian company that succeeds to bring modified cassava flour internationally. They have a state-of-theart website and actively reaching the public using social media, such as Instagram, spreading their products uses and building stronger public affection to local products.

Indonesian Association of Food Technologists (IAFT) could maximize their contribution to the development and application of food technology in Indonesia, by following the steps described previously and encouraging the food technologists to contribute in scientific activities. The branches of IAFT in Indonesia provinces could help to improve local home-scale food industries therefore they can increase the quality and safety of their products, and even distributing their products internationally.

\section{CONCLUSION}

Indigenous foods could answer the food security problem and future threat, especially the physical availability of food, by optimizing human resources and technology. Indonesia has many potential area-specific commodities such as cassava, purple sweet potato, sago, and fish. The application of science and technology to these commodities in each area will increase the quality of indigenous food. In this case, food technologies have a very important role. The main role of food technologists is to explore the potential application of food and enhance their values using food technology with all its advances. The main steps to develop indigenous food are choosing potential raw material, assessing its superiorities, doing a feasibility study, enhancing the food product's safety and quality, and promoting it through modern channels. This would allow 
nutritious and safe indigenous food products to become competitive and widely impacting and bring food security into a reality.

\section{REFERENCES}

[BKP] Badan Ketahanan Pangan. Data statistik ketahanan pangan tahun 2014. http://bkp.pertanian.go.id/tinymcpuk/gambar/file/data statistik_kp_2014_new.pdf, 2015.

[FAO] Food and Agriculture Organization, An introduction to the basic concepts of food security. http://www.foodsec.org/docs/concepts guide.pdf, 2008.

[FAO] Food and Agriculture Organization, Promotion of underutilized indigenous food resources for food security and nutrition in Asia and the Pacific. FAO, Bangkok, 2014.

[UN] United Nations, World population prospects: the 2015 revision, key findings and advance tables. Working paper no. ESA/P/WP/.241. http://esa.un.org/unpd/wpp/Publications/Files/Key_Findings WPP 2015.pdf, 2015.

[WFP] World Food Programme, Hunger glossary. http://www.wfp.org/ hunger/glossary, 2015.

A. Farhan, and N.M. Hani, Characterization of edible packaging films based on semi-refined kappa-carrageenan plasticized with glycerol and sorbitol, Food Hydrocolloids. 64 (2017) 48-58.

A.E. Sloan, The top ten food trends. http://www.ift.org/foodtechnology/past-issues/2015/april/features/the-top-ten-food-trends. aspx?page= viewall, 2015.

F. Bourdichon, S. Casaregola, C. Farrokh, J.C. Frisvad, M.L. Gerds, W.P. Hammes, ... and I.B. Powell, Food fermentations: microorganisms with technological beneficial use, International journal of food microbiology. 154 (3) (2012) 87-97.

FAO, IFAD and WFP, The state of food Insecurity in the world 2015: Meeting the 2015 international hunger targets: taking stock of uneven progress. FOA, Rome, 2015.

G.K. Rana, Papeda sago porridge, a staple food in Indonesia, in D. Patrick, and B. Nomindelger, (ed.), Promotion of underutilized indigenous food resources for food security and nutrition in Asia and the Pacific, FAO, Bangkok, 2014.
H. Wolinsky, 3-D food printing reaches for the stars. http://futurefood2050. com/3-d-food-printing-reaches-for-the-stars, 2014.

I. Rastika, WFP: 15 persen dari 398 kabupaten masih rawan pangan. http://nasional.kompas.com/read/2015/07/08/12523501/WFP.15. Persen.dari.398.Kabupaten.Masih.Rawan.Pangan\#page1, 2015.

K. Tontisirin, Promotion of underutilized indigenous food resources for food security and nutrition in Asia and the Pacific. In D. Patrick, and B. Nomindelger, (eds.)., Promotion of underutilized indigenous food resources for food security and nutrition in Asia and the Pacific. FAO, Bangkok, 2014.

M. Gardjito, A. Djuwardi, and E. Harmayani, Pangan nusantara: karakteristik dan prospek untuk percepatan diversifikasi pangan, $1^{\text {st }}$ ed., Kencana Prenada Media Group, Jakarta, 2013.

N. Lutaladio, B. Burlingame, and J. Crews, Horticulture, biodiversity and nutrition. Journal of Food Composition and Analysis. 23 (2010) 481485.

Q. Zheng, Y. Tian, F. Ye, Y. Zhou, and G. Zhao, Fabrication and application of starch-based aerogel: Technical strategies, Trends in Food Science \& Technology. 99 (2020) 608-620.

R. Mohanraj, and S. Sivasankar, Sweet potato (Ipomoea batatas [L.] Lam) - a valuable medicinal food: a review, Journal of Medical Food. 17 (7) (2014) 733-741.

W.P. Rahayu, and L.K. Lian, The uniqueness of Asean food, IPB Press, Bogor, Indonesia, 2020.

World Food Summit, Rome declaration on world food security and world food summit plan of action. http://www.fao.org/docrep/003/w3613e/ w3613e00.HTM, 1996.

X. Yu, J. Zhang, Z. Wang, and F. Xiong, Morphology and physicochemical properties of 3 lilium bulb starches, Journal of Food Science 80 (8) (2015) C1661-1669.

Y. Zhu, C. Li, H. Cui, and L. Lin, Feasibility of cold plasma for the control of biofilms in food industry, Trends in Food Science \& Technology. 99 (2020) 142-151.

Z.F. Bhat, S. Kumar, and H. F. Bhat, In vitro meat: A future animal-free harvest, Critical reviews in food science and nutrition. 57 (4) (2017) 782-789. 